\title{
Radical scavenging-linked anti-adipogenic activity of Alnus firma extracts
}

\author{
SUN-IL CHOI ${ }^{1}$, JONG SEOK LEE ${ }^{2}$, SARAH LEE ${ }^{2}$, JIN-HA LEE ${ }^{1}$, HEE-SUN YANG ${ }^{2}$, JOOHONG YEO ${ }^{2}$, \\ JONG-YEA KIM ${ }^{1}$, BOO-YONG LEE ${ }^{3}$, IL-JUN KANG ${ }^{4}$ and OK-HWAN LEE ${ }^{1}$ \\ ${ }^{1}$ Department of Food Science and Biotechnology, Kangwon National University, Chuncheon, Gangwon 24341; \\ ${ }^{2}$ National Institute of Biological Resource, Incheon 22689; ${ }^{3}$ Department of Food Science and Biotechnology, \\ CHA University, Seongnam, Gyeonggi 13488; ${ }^{4}$ Department of Food Science and Nutrition, \\ Hallym University, Chuncheon, Gangwon 24252, Republic of Korea
}

Received March 19, 2017; Accepted October 24, 2017

DOI: 10.3892/ijmm.2017.3221

\begin{abstract}
The purpose of the present study was to investigate the antioxidant activity and anti-adipogenic effect of extracts from Alnus firma (A. firma), which is an edible plant that grows in mountainous areas. The total phenolic, flavonoid and anthocyanin content as well as the antioxidant activity of a $70 \%$ ethanolic extract of A. firma (AFE) was assessed. Furthermore, the effects of AFE on lipid accumulation and reactive oxygen species (ROS) production during adipogenesis of 3T3-L1 cells were investigated. The results revealed that the total phenolic, flavonoid and pro-anthocyanidin content of AFE as $436.26 \pm 3.30 \mathrm{mg}$ gallic acid equivalents $/ \mathrm{g}, 73.82 \pm 0.54 \mathrm{mg}$ quercetin equivalents/g and $149.25 \pm 6.06 \mathrm{mg}$ catechin equivalents/g, respectively. In addition, AFE exerted significant antioxidant effects in terms of 1,1-diphenyl-2-picryl hydrazyl radical scavenging activity, 2,2'-azino-bis(3-ethylbenzothiazoline-6-sulfonic acid) radical scavenging activity, reducing power, oxygen radical absorbance capacity and nitric oxide radical scavenging activity. As for its anti-adipogenic activity, AFE significantly inhibited ROS production and lipid accumulation during adipogenesis of 3T3-L1 cells compared with those in control cells. In addition, AFE regulated adipogenic transcription factors including peroxisome proliferator-activated receptor- $\gamma$, CCAAT/enhance-binding protein $\alpha$ and adipocyte protein 2 . These results indicated that A. firma is a potential candidate for a functional food supplement.
\end{abstract}

Correspondence to: Professor Ok-Hwan Lee, Department of Food Science and Biotechnology, Kangwon National University, 1 Gangwondaehak-gil, Chuncheon, Gangwon 24341, Republic of Korea

E-mail: loh99@kangwon.ac.kr

Abbreviations: ROS, reactive oxygen species; ORAC, oxygen radical absorbance capacity; ORO, Oil Red O; PPAR- $\gamma$, peroxisome proliferator-activated receptor $\gamma ; \mathrm{C} / \mathrm{EBP}-\alpha, \mathrm{CCAAT} / \mathrm{enh}$ ancer-binding protein $\alpha$; aP2, adipocyte protein 2

Key words: Alnus firma, anti-oxidant assay, anti-adipogenic, 3T3-L1, total phenolic content

\section{Introduction}

Recent industrial advancements have resulted in rapid social changes, including changes in everyday lifestyle and worsening of environmental pollution. In particular, various mental and physical pathologies have accelerated the rate of chronic metabolic diseases, including obesity, cerebrovascular disease, heart disease and hypertension (1). The major causes of chronic degenerative diseases are reactive oxygen species (ROS), comprising superoxide $\left(\mathrm{O}^{2-}\right)$, singlet oxygen $\left({ }^{1} \mathrm{O}_{2}\right)$ and hydrogen peroxide $\left(\mathrm{H}_{2} \mathrm{O}_{2}\right)$, which are produced during metabolic processes. ROS generated in the body are the cause of oxidative stress $(2,3)$. They are not only involved in processes of energy metabolism, immune reaction and neuronal signal transduction, but when they are produced excessively, ROS also have a role in various dysfunctions, including protein and DNA modification, aging of biological membranes, metabolic diseases and cancer $(4,5)$.

Obesity arises from the accumulation of triglycerides in the body, resulting from an imbalance in the use and intake of energy from food. A typical disease caused by obesity is insulin resistance and diabetic dyslipidemia $(6,7)$. The cause of the lipid accumulation is the differentiation of preadipocytes to adipocytes. This differentiation leads to hypertrophy and hyperplasia of adipocytes $(8,9)$. In addition, when the preadipocytes differentiate to adipocytes, the expression of oxidant enzymes, such as NADPH oxidase, is increased. Therefore, adipocyte differentiation generates ROS and leads to oxidative stress (10).

For the maintenance of the anti-oxidative system, a healthy functional diet is required so that individuals with a modern lifestyle, who are exposed to a high frequency of stress, obesityassociated factors, chemicals and environmental hormones may compensate for the risk these factors represent for their health $(11,12)$. A healthy functional diet contains radicalquenching substances that exert a protective mechanism to remove toxic ROS (13). These foods are required to contain high quantities of ascorbic acid, $\alpha$-tocopherol, glutathione, phenolics and flavonoids that protect against oxidative damage by removing ROS (14).

Of note, due to the increasing demand for more effective and safer in anti-obesity and antioxidant products, it is 
important to identify novel natural substances that serve this purpose. Therefore, the present study was designed to investigate the antioxidant and anti-obesity effects of Alnus firma, which is common in South Korea, to observe its inhibitory effects on lipid accumulation and ROS generation.

\section{Materials and methods}

Materials. The leaves of Alnus firma (A. firma) 70\% ethanolic extract (AFE) were prepared as follows: A. firma was collected in Goryeong-gun (Gyeongsangbuk-do, Korea) in July 2014 and identified by the National Institute of Biological Resources (Incheon, Korea). A sample was also deposited in a library of the National Institute of Biological Resources. Coarse, grounded, dried samples $(100 \mathrm{~g})$ were extracted with $1,000 \mathrm{ml} 70 \%$ ethanol at room temperature for $24 \mathrm{~h}$. The extraction process was repeated three times. The extracted materials were filtered (no. 3; Whatman; GE Healthcare, Little Chalfont, UK) and concentrated with a rotary evaporator (N-3000; Eyela, Tokyo, Japan). Subsequently, the extracted materials were dried using a freeze dryer (Biotron, Bucheon, Korea). The extracts obtained after freeze drying weighed $12.7 \mathrm{~g}$, with a yield of $12.70 \%$. The samples were dissolved in dimethyl sulfoxide (DMSO) to prepare a stock solution used in the experiments. Oil Red O, 3-isobutyl-1-methylxanthine (IBMX), dexamethasone (DEX), isopropanol, rutin, ascorbic acid, gallic acid, 1,1-diphenyl2-picryl hydrazyl radical (DPPH), N-acetyl-L-cysteine (NAC), 2,2'-azino-bis(3-ethylbenzothiazoline-6-sulfonic acid) diammonium salt (ABTS), Folin-Ciocalteu phenol reagent, potassium ferricyanide, sodium carbonate, potassium persulfate, 6-hydroxy-2,5,7,8-tetramethylchroman-2-carboxylic acid (Trolox), insulin, acetic acid, 2,2-azobis(2-amidinopropane) dihydrochloride (AAPH), fluorescein sodium salt and sodium nitrite were from Sigma-Aldrich (Merck KGaA, Darmstadt, Germany). Dulbecco's modified Eagle's medium (DMEM), bovine serum (BS), fetal bovine serum (FBS), penicillinstreptomycin $(\mathrm{P} / \mathrm{S})$, phosphate-buffered saline $(\mathrm{PBS})$ and trypsin-EDTA were from Gibco (Thermo Fisher Scientific, Inc., Waltham, MA, USA).

Total phenolic, flavonoid and proanthocyanidin contents. The total phenolic content of AFE was determined by the method of Gutfinger (15) with certain modifications. The sample dissolved in $100 \%$ DMSO solution $(1 \mathrm{ml})$ was placed in a test tube with $(2 \%)$ sodium carbonate solution $(1 \mathrm{ml})$ and $10 \%$ Folin-Ciocalteu reagent $(1 \mathrm{ml})$. After the mixture was incubated at $25^{\circ} \mathrm{C}$ for $40 \mathrm{~min}$, the absorbance was measured at $750 \mathrm{~nm}$ and the calibration curve was prepared using gallic acid. The results are expressed in milligram of gallic acid equivalents (mg GAE)/g.

The total flavonoid content of AFE was determined by the method of Moreno et al (16) with certain modifications. The sample dissolved in $100 \%$ DMSO solution $(0.5 \mathrm{ml})$ was mixed with $0.5 \mathrm{ml}$ aluminum chloride $(2 \% \mathrm{w} / \mathrm{v})$. After incubation at room temperature for $60 \mathrm{~min}$, the absorbance was determined at $420 \mathrm{~nm}$, and a calibration curve was prepared using quercetin. The results are expressed in milligram of quercetin equivalents (mg QE)/g.

The total proanthocyanidin content of AFE was determined by the method of Mitsunaga et al (17) with certain modifications. The sample $(0.5 \mathrm{mg})$ was diluted with $5 \mathrm{ml}$ methanol. The sample solution was mixed with $3 \mathrm{ml}$ vanillin (4\% w/v) and $1.5 \mathrm{ml}$ concentrated hydrochloric acid. After the mixture was incubated at room temperature for $15 \mathrm{~min}$, the absorbance was determined at $429 \mathrm{~nm}$, and a calibration curve was prepared using catechin. The results are expressed in milligram of catechin equivalents (mg CE)/g.

DPPH radical scavenging assay. The DPPH assay was performed according to the method of Chu et al (18) with certain modifications. The sample solution $(0.1 \mathrm{ml})$ was mixed with $0.4 \mathrm{mM}$ DPPH solution $(0.1 \mathrm{ml})$ in anhydrous ethanol and the mixture was incubated in the dark for $30 \mathrm{~min}$. The absorbance of the solution was adjusted to $1.0 \pm 0.1$ at $515 \mathrm{~nm}$. Subsequently, $0.2 \mathrm{ml}$ of the sample (or a control) was mixed with $0.8 \mathrm{ml} \mathrm{DPPH}$ solution and incubated for $10 \mathrm{~min}$ in the dark at room temperature. The decrease in absorbance was measured at $515 \mathrm{~nm}$, and the radical scavenging activity was calculated and expressed as a percentage using the following formula: DPPH radical scavenging activity $(\%)=[(\mathrm{Ac}-\mathrm{As}) / \mathrm{Ac}] \times 100(\mathrm{i})$, with Ac being the absorbance of the control and As the absorbance of the sample.

ABTS radical scavenging activity. The ABTS assay was based on the method of Re et al (19) with certain modifications. ABTS (7 mM) dissolved in water was mixed with $2.45 \mathrm{mM}$ potassium persulfate. The mixture was incubated in the dark at $20^{\circ} \mathrm{C}$ for $16 \mathrm{~h}$. The ABTS solution was diluted with ethanol until an absorbance of $0.70 \pm 0.02$ was achieved at $734 \mathrm{~nm}$. Subsequently, $150 \mu \mathrm{l}$ ABTS solution was added to $50 \mu \mathrm{l}$ of the sample solutions. After $20 \mathrm{~min}$, the absorbance of the mixture was measured at $734 \mathrm{~nm}$. The ABTS radical scavenging activity was calculated and expressed as a percentage using formula (i).

Reducing power. The reducing power assay was performed according to the method of Oyaizu (20) with certain alterations. Various concentrations of sample solutions were mixed with $0.5 \mathrm{ml}$ sodium phosphate buffer $(0.2 \mathrm{M})$ and $0.5 \mathrm{ml}$ potassium ferricyanide $(1 \% \mathrm{v} / \mathrm{v})$. The mixtures were incubated at $50^{\circ} \mathrm{C}$ for $20 \mathrm{~min}$. After the addition of $0.5 \mathrm{ml}$ trichloroacetic acid $(10 \% \mathrm{w} / \mathrm{v})$, the mixture was centrifuged at $1,790 \mathrm{x} \mathrm{g}$ for $10 \mathrm{~min}$. A $2.5-\mathrm{ml}$ aliquot of the supernatant was mixed with $2.5 \mathrm{ml}$ distilled water and $0.2 \mathrm{ml}$ Iron(III) chloride $(0.1 \% \mathrm{w} / \mathrm{v})$, and the absorbance was measured at $700 \mathrm{~nm}$.

Nitrate scavenging ability assay. The nitric oxide (NO) assay was performed according to the method of Kato et al (21) with certain modifications. Sample solution $(0.5 \mathrm{ml})$ was mixed with $0.5 \mathrm{ml}$ sodium nitrite solution $(1 \mathrm{mM})$. The mixture was calibrated at $\mathrm{pH} 1.2$ with $\mathrm{HCl}(0.1 \mathrm{~N})$ and filled up to a volume of $5 \mathrm{ml}$ with distilled water. The mixture was then incubated at $37^{\circ} \mathrm{C}$ for $60 \mathrm{~min}$. Subsequently, $1 \mathrm{ml}$ of the solution was mixed with $5 \mathrm{ml}$ acetic acid $(2 \% \mathrm{v} / \mathrm{v})$ and $0.4 \mathrm{ml}$ Griess reagent (0.5\% sulfanilic acid and $0.5 \%$ naphthylamine in $30 \%$ acetic acid). The mixture was incubated at room temperature for $60 \mathrm{~min}$ and the absorbance was measured at $734 \mathrm{~nm}$. The NO radical scavenging activity was calculated and expressed as a percentage using formula (i).

Oxygen radical absorbance capacity (ORAC) assay. The ORAC assay was based on the method of Ou et al (22) with 
certain modifications. AFE was dissolved in $75 \mathrm{mM}$ phosphate buffer ( $\mathrm{pH} \mathrm{7.4)} \mathrm{at} 37^{\circ} \mathrm{C}$. Aliquots of $25 \mu \mathrm{l}$ of this solution, $150 \mu 1$ fluorescein $(40 \mathrm{nM})$ and $25-\mu 1$ AAPH $(18 \mathrm{mM})$ were filled into each well of black 96 -well plates and incubated at $37^{\circ} \mathrm{C}$ for $15 \mathrm{~min}$. The plate was then immediately placed in the fluorescence microplate reader (Spectramax Gemini EM; Molecular Devices, Sunnyvale, CA, USA). The reader was programmed to record the fluorescence of fluorescein every 3 for $90 \mathrm{~min}$ at emission and excitation wavelengths of 520 and $485 \mathrm{~nm}$, respectively. Trolox was used as a standard, and a blank was measured that contained phosphate buffer in place of the sample. The ORAC values were calculated using a Trolox calibration curve and the area under the fluorescence decay curve. ORAC values were expressed as TE in $\mu \mathrm{mol} / \mathrm{ml}$ and the area under the curve (AUC) was determined as follows: $\mathrm{AUC}=1+\mathrm{f} 1 / \mathrm{f} 0+\mathrm{f} 2 / \mathrm{f} 0+\mathrm{f} 3 / \mathrm{f} 0+\mathrm{f} 4 / \mathrm{f} 0+\ldots \mathrm{f} / 31 / \mathrm{f} 0$ (ii), with $\mathrm{f}(0)$ being the initial fluorescence values and $f(n)$ the fluorescence value measured every $3 \mathrm{~min}$.

Cell culture. 3T3-L1 preadipocytes obtained from the American Type Culture Collection (no. CL-173; Manassas, VA, USA) were cultured, maintained and differentiated as described by Lee et al (23). In brief, the cells were plated in a $5 \% \mathrm{CO}_{2}$ atmosphere at $37^{\circ} \mathrm{C}$ and grown in DMEM with $3.7 \mathrm{~g} / 1$ sodium bicarbonate, $1 \% \mathrm{P} / \mathrm{S}$ and $10 \% \mathrm{BS}$. Adipocyte differentiation was induced by treating post-confluent cells with $10 \%$ FBS and a hormonal cocktail consisting of $0.5 \mathrm{mM}$ IBMX, 1.0 $\mu \mathrm{M}$ DEX, and 1.0 $\mu \mathrm{M}$ insulin (MDI) for 2 days. The culture medium was then replaced with DMEM supplemented with $1.67 \mu \mathrm{M}$ insulin and $10 \%$ FBS only. 3T3-L1 cells were grown in 100-mm tissue culture dishes in DMEM supplemented with $10 \% \mathrm{BS}$, as previously described. When the cells were in the log phase, they were divided into suitable dishes for the study. This medium was then replenished every 2 days. For the treatments, 2-days post-confluent cells were differentiated with MDI in the presence of AFE $(25,50$ or $100 \mu \mathrm{g} / \mathrm{ml})$ or NAC $(5 \mathrm{mM})$. AFE was prepared at 25,50 and $100 \mathrm{mg} / \mathrm{ml}$ in DMSO and then diluted to $0.1 \%$ with media.

Cell proliferation assay. Cell proliferation was assessed using the 2,3-bis(2-methoxy-4-nitro-5-sulfophenyl)-2H-tetrazolium-5-carboxanilide inner salt (XTT) assay (WelGene, Seoul, Korea). When the cells were cultured to be in the log phase, they were seeded on a 96 -well plate $\left(1 \times 10^{5}\right.$ cells/well $)$ and incubated for $24 \mathrm{~h}$. The cells were divided into a control group and the treatment groups, which were treated at the concentrations indicated. The absorbance (A) was determined with an enzyme calibrator at $450 \mathrm{~nm}$. The cell viability was determined as follows: Viability $=$ (A study group/A of control group) x100\% (iii).

Determination of ROS by flow cytometry. The levels of ROS were analyzed using 2',7'-dichlorodihydrofluorescein diacetate $\left(\mathrm{H}_{2} \mathrm{DCFDA}\right.$; Invitrogen; Thermo Fisher Scientific, Inc.). In brief, the 3T3-L1 cells were differentiated with AFE for 6 days. Differentiated cells were incubated for at $37^{\circ} \mathrm{C}$ with $\mathrm{H}_{2}$ DCFDA $(10 \mu \mathrm{M})$ for $30 \mathrm{~min}$. The cell pellet was analysed using a FACSCalibur flow cytometer (BD Biosciences, San Jose, CA, USA), with an excitation wavelength of $488 \mathrm{~nm}$ and an emission wavelength of $545 \mathrm{~nm}$. Data analysis was based on 10,000 detected events using Cell Quest software 6.0 (BD Biosciences).

Nitroblue tetrazolium (NBT) assay. 3T3-L1 preadipocytes were grown to confluence and induced to differentiate into adipocytes as previously described (24). ROS production was detected by an NBT assay. NBT is reduced by ROS to a dark blue, insoluble form of NBT called formazan. At 8 days after induction, the cells were incubated in PBS containing $0.2 \% \mathrm{NBT}$ for $90 \mathrm{~min}$. The formazan was dissolved in $50 \%$ acetic acid and the absorbance was determined at $570 \mathrm{~nm}$. NBT assay was calculated and expressed as a percentage using formula (iii).

Oil Red $O$ staining. The extent of differentiation was determined by the amount of lipid accumulation after 8 days following induction of differentiation by Oil Red $\mathrm{O}$ staining. In brief, the cells were fixed in $10 \%$ formaldehyde in distilled water for $1 \mathrm{~h}$, washed with distilled water and completely dried. The cells were stained with $0.5 \%$ Oil Red O dissolved in isopropanol $(60 \% \mathrm{v} / \mathrm{v})$ for $30 \mathrm{~min}$ at room temperature, washed four times with water and dried. Differentiation was also monitored under a microscope and quantified via elution with isopropanol. The optical density at $490 \mathrm{~nm}\left(\mathrm{OD}_{490}\right)$ was then measured (25). Oil Red $\mathrm{O}$ staining was calculated and expressed as a percentage using formula (iii).

RNA extraction and semi-quantitative reverse transcriptionpolymerase chain reaction $(R T-P C R)$. Total RNA was extracted from mature 3T3-L1 adipocyte cells with TRIzol reagent (Invitrogen; Thermo Fisher Scientific, Inc.) in accordance with the manufacturer's recommended protocols. RNA samples with $\mathrm{OD}_{260} / \mathrm{OD}_{280}$ ratios $>2.0$ were employed for semi-quantitative RT-PCR. One microgram of total RNA was employed for the production of complementary DNA using a Maxime RT premix kit (Intron Biotechnology, Inc., Seongnam, Korea) at $45^{\circ} \mathrm{C}$ for $60 \mathrm{~min}$ and an RT-PCR system (c1000 thermal cycler; Bio-Rad Laboratories, Inc., Hercules, CA, USA). PCR amplification was performed with primers, cDNA and Taq MasterMix (MG Taq MasterMix; Doctor Protein; MGMED, Inc., Seoul, Korea), and it was performed at $95^{\circ} \mathrm{C}$ for $5 \mathrm{~min}$, followed by 30 cycles of $95^{\circ} \mathrm{C}$ for $30 \mathrm{sec}$, annealing for $30 \mathrm{sec}$ at $54^{\circ} \mathrm{C}$ and an extension step of $1 \mathrm{~min}$ at $72^{\circ} \mathrm{C}$, and a final extension step of $5 \mathrm{~min}$ at $72^{\circ} \mathrm{C}$. All primers used in this study are listed in Table I. The PCR products were then run on $1.5 \%(\mathrm{v} / \mathrm{v})$ agarose gels and stained with ethidium bromide, and images were captured with a gel documentation and analysis system (care stream MISE; Carestream Health, Inc., Rochester, NY, USA). The expression levels were quantified using ImageJ software 1.48 (National Institutes of Health, Bethesda, MD, USA).

Western blot analysis. For western blot analysis, cells were lysed using a protein lysis buffer containing $50 \mathrm{mM}$ Tris-HCL at $\mathrm{pH} 7.4,150 \mathrm{mM} \mathrm{NaCl}, 1 \% \mathrm{NP}-40,0.25 \%$ sodium deoxycholate, $0.1 \%$ SDS, $1 \mathrm{mM}$ PMSF and $1 \mathrm{mM}$ pepstatin $\mathrm{A}$. The lysates were centrifuged at $12,000 \mathrm{x}$ for $20 \mathrm{~min}$ at $4^{\circ} \mathrm{C}$, and the protein concentrations were determined using a Bradford protein assay kit (Bio-Rad Laboratories, Inc.). Equal volumes of supernatant $(30 \mu \mathrm{g})$ were separated by $10 \%$ sodium dodecyl 
Table I. Gene specific primer used for RT-PCR.

\begin{tabular}{lcc}
\hline Gene & \multicolumn{1}{c}{ Primer sequences $\left(5^{\prime}-3^{\prime}\right)$} \\
\hline PPAR- $\gamma$ & F: & CCA GAG TCT GCT GAT CTG CG \\
& R: & GCC ACC TCT TTG CTC TGA TC \\
C/EBP- $\alpha$ & F: & GCA GTG TGC ACG TCT ATG CT \\
& R: & AGC CCA CTT CAT TTC ATT GG \\
aP2 & F: & GAC CTG GAA ACT CGT CTC CA \\
& R: & CAT GAC ACA TTC CAC CAC CA \\
$\beta$-actin & F: & ATG GAT GAC GAT ATC GCT GC \\
& R: & GCT GGA AGG TGG ACA GTG AG
\end{tabular}

RT-PCR, reverse transcription-polymerase chain reaction; aP2, adipo-

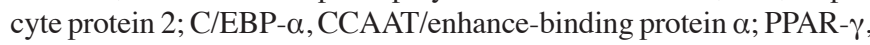
peroxisome proliferator-activated receptor- $\gamma ; \mathrm{F}$, forward; R, reverse.

sulfate-polyacrylamide gel electrophoresis (SDS-PAGE) and transferred onto a polyvinylidene difluoride membrane (Bio-Rad Laboratories, Inc.). Nonspecific binding was blocked using Tris-buffered saline containing Tween-20 (TBS-T) and $5 \%$ skimmed milk for $1 \mathrm{~h}$ and the membranes were incubated with primary antibodies at $4^{\circ} \mathrm{C}$ overnight. Finally, the membranes were treated with secondary antibodies for $1 \mathrm{~h}$ at room temperature and washed with TBS-T. Each protein was detected using Super Signal West Pico Chemiluminescence detection reagents (Pierce; Thermo Fisher Scientific, Inc.), and images were evaluated using Chemi Doc image software 5.2.1 (Bio-Rad Laboratories, Inc.). The primary antibodies specific for $\beta$-actin $(1: 1,000$; cat. no. 4967), peroxisome proliferatoractivated receptor- $\gamma$ (PPAR- $\gamma ; 1: 1,000$; cat. no. 2443), CCAAT/enhancer-binding protein- $\alpha$ (C/EBP- $\alpha ; 1: 1,000$; cat. no. 2295), adipocyte protein 2 (aP2; 1:1,000; cat. no. 3544) and the secondary antibodies $(1: 3,000$; cat. no. 7076) were obtained from Cell Signalling Technology (Danvers, MA, USA).

Statistical analysis. All measurements were repeated three times. Values are expressed as the mean \pm standard deviation. The results were statistically analyzed by analysis of variance and Duncan's multiple-range tests. $\mathrm{P}<0.05$ was considered to indicate a statistically significant difference. SAS software 9.4 (1998; SAS Institute, Inc., Cary, NC, USA) was used for all statistical comparisons.

\section{Results}

Total phenolic, flavonoid and proanthocyanidin contents. Phenols are aromatic compounds bearing hydroxyl groups (-OH). These phenolic compounds have antioxidant capacities and protect DNA, cell proteins and enzymes when exposed to ROS, thereby exerting anticancer and other protective effects. Due to their antioxidant effects, the increased total phenolic content achieved by $A$. firma supplementation increases the physiological antioxidant activity $(26,27)$. Flavonoids and proanthocyanidins, which are polyphenol compounds contained in the roots, stems, leaves, flowers and fruits of
Table II. Quantification of antioxidant components in $70 \%$ ethanolic extract of Alnus firma.

\begin{tabular}{lc}
\hline Compound class & Amount \\
\hline Total phenols & $436.26 \pm 3.30 \mathrm{mg} \mathrm{GAE} / \mathrm{g}$ \\
Total flavonoids & $73.82 \pm 0.54 \mathrm{mg} \mathrm{QE} / \mathrm{g}$ \\
Total proanthocyanidins & $149.25 \pm 6.06 \mathrm{mg} \mathrm{CE} / \mathrm{g}$ \\
\hline
\end{tabular}

GAE, gallic acid equivalents; $Q E$, quercetin equivalents; $C E$, catechin equivalents.

numerous plants, have also been reported to have antioxidant, anti-bacterial, anti-allergic, anticancer and anti-inflammatory effects $(28,29)$. The present study examined the total phenolic, flavonoid and proanthocyanidin contents of AFE (Table II). It had a high total phenolic content $(436.26 \pm 3.30 \mathrm{mg} \mathrm{GAE} / \mathrm{g})$, total flavonoid content $(73.82 \pm 0.54 \mathrm{mg} \mathrm{QE} / \mathrm{g})$ and total anthocyanin content $(149.25 \pm 6.06 \mathrm{mg} \mathrm{CE} / \mathrm{g})$. These results are in good agreement with another study by Stević et al (30), according to which the total phenolic content of other species of the Alnus genus, methanolic extract of A. incana and A. viridis, were $316.2 \pm 6.9$ and $238.6 \pm 6.6 \mathrm{mg} \mathrm{GAE} / \mathrm{g}$, respectively. Futhermore, Acero and Muñoz-Mingarro (31) reported that the total flavonoid content of methanolic extract of A. glutinosa, another species of the Alnus genus, was $34.55 \pm 0.19 \mathrm{mg}$ $\mathrm{QE} / \mathrm{g}$. Therefore, these results indicated that AFE, compared with the extracts of other Alnus species, contained high levels of flavonoids and phenolic compounds.

Effect of AFE on antioxidant activity. In order to measure the antioxidant activity of AFE, in vitro assays assessing parameters including the DPPH radical scavenging activity, ABTS radical cation scavenging activity, reducing power and nitrite scavenging ability (Fig. 1), as well as the ORAC (Fig. 2) were used. These assays measure the antioxidant and radical quenching capacity of AFE through different mechanisms. The DPPH radical scavenging activity of AFE was dose-dependent, and scavenging of $38.57 \pm 1.04,53.63 \pm 2.68$ and $66.16 \pm 4.54 \%$ of DPPH was obtained with $12.5,25$ and $50 \mu \mathrm{g} / \mathrm{ml} \mathrm{AFE}$, respectively (Fig. 1A). ABTS radical scavenging proceeds via a similar mechanism to that of DPPH radical scavenging, and was also dose-dependent with 32.09 $\pm 1.11,50.29 \pm 2.74$ and $88.19 \pm 1.47 \%$ ABTS scavenging obteined with 12.5, 25 and $50 \mu \mathrm{g} / \mathrm{ml}$ AFE, respectively (Fig. 1B). However, as the DPPH assay cancels out the free radicals whereas the ABTS assay cancels out cation radicals, a discrepancy in radical scavenging ability between the DPPH assay and the ABTS assay was observed, which may indicate a combination of reactant and substrate at different degrees (32). The nitrite scavenging ability and reducing power assays, which demonstrate the antioxidant effect of AFE, are based on different mechanisms. One of the radicals of nitrite reacts with the Griess reagent to form a purple Azo-dye. The nitrite scavenging activities were $17.19 \pm 1.89,29.23 \pm 1.43$ and $61.30 \pm 0.34 \%$ for $12.5,25$ and $50 \mu \mathrm{g} / \mathrm{ml} \mathrm{AFE}$, respectively (Fig. 1D). The reducing power assay is a method to measure the degree of reduction from oxidation of the analyte substance. AFE (12.5 to 25 to $50 \mu \mathrm{g} / \mathrm{ml})$ 
A

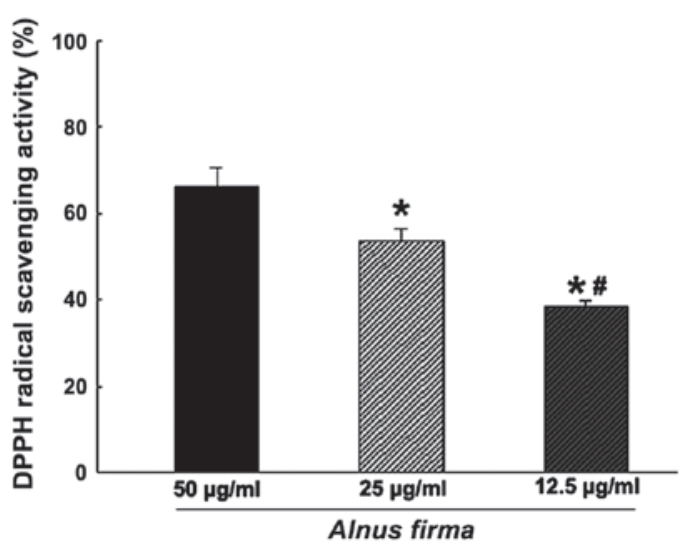

C

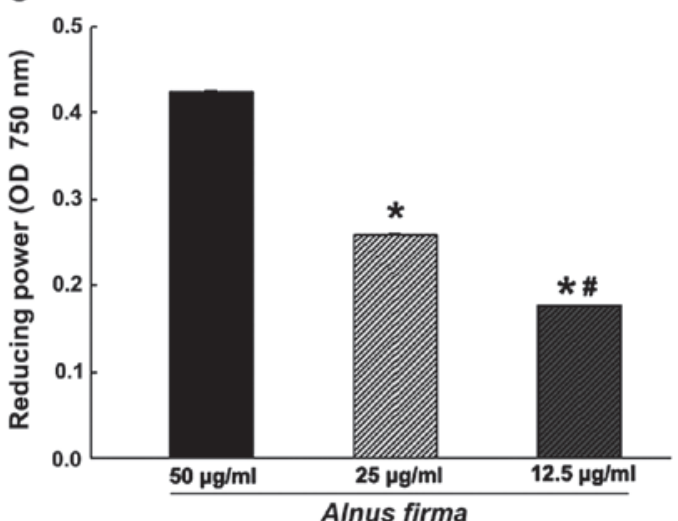

B

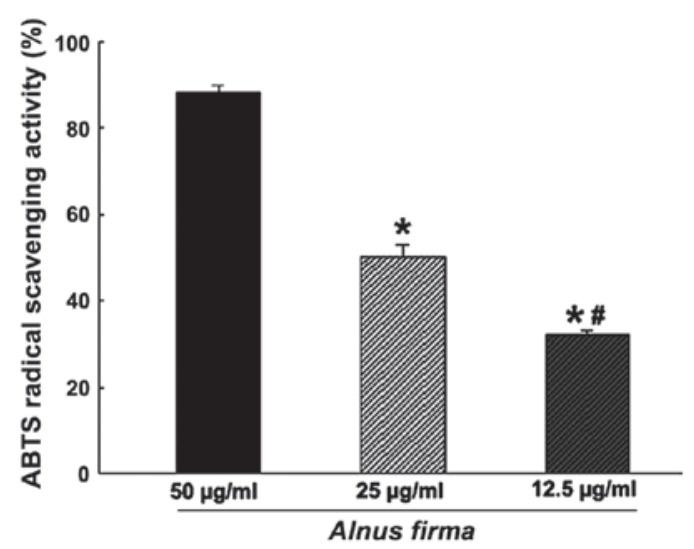

D

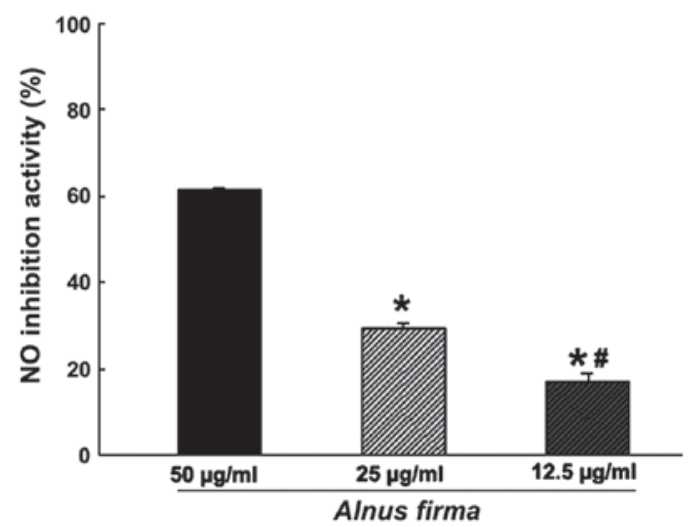

Figure 1. (A) DPPH radical scavenging activity, (B) ABTS radical scavenging activity, (C) reducing power and (D) NO scavenging ability of Alnus firma at various concentrations. All values are expressed as the mean \pm standard deviation. ${ }^{*} \mathrm{P}<0.05 \mathrm{vs} .50 \mu \mathrm{g} / \mathrm{ml} ;{ }^{*} \mathrm{P}<0.05 \mathrm{vs} .25 \mu \mathrm{g} / \mathrm{ml}$, according to one-way analysis of variance. NO, nitric oxide; DPPH, 1,1-diphenyl-2-picryl hydrazyl radical; ABTS, 2,2'-azino-bis(3-ethylbenzothiazoline-6-sulfonic acid); OD, optical density.
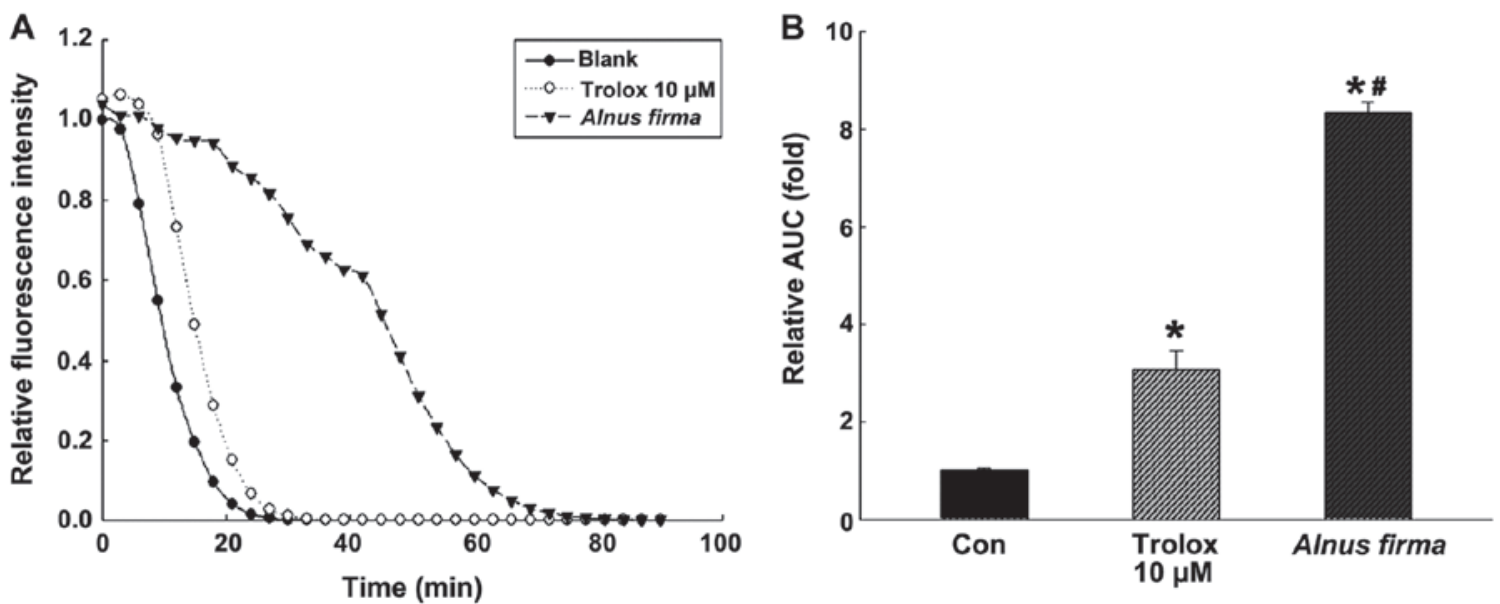

Figure 2. Radical scavenging activity of AFE as measured by an oxygen radical absorbance capacity assay. (A) Decay curve of fluorescence in the presence or absence of blank, Trolox $(10 \mu \mathrm{M})$ and AFE $(10 \mu \mathrm{g} / \mathrm{ml})$. (B) Radical scavenging activity of AFE expressed in TE. All values are expressed as the mean \pm standard deviation. ${ }^{*} \mathrm{P}<0.05$ vs. con; ${ }^{*} \mathrm{P}<0.05$ vs. Trolox $10 \mu \mathrm{M}$, according to one-way analysis of variance. AFE, $70 \%$ ethanolic extract of Alnus firma; AUC, area under curve; con, control; TE, Trolox equivalents.

was determined to have dose-dependent nitrite-scavenging and reducing capacities (Fig. 1C and D). The ORAC assay is a measure of the reduction of fluorescence by the peroxyl radical (Fig. 2). The ORAC of AFE was $792.01 \pm 13.10 \mu \mathrm{M}$ Trolox equivalents (TE)/g when it was created by Trolox standard curve (data not shown). Kim et al (33) reported that the ORAC value of methanolic extract of $A$. firma was 198.0 $\pm 9.1 \mu \mathrm{M} \mathrm{TE} / \mathrm{g}$, which differed from the result of the present study.

Effect of AFE on cell viability. In order to determine the cytotoxicity and the concentration range of AFE suitable for 
A

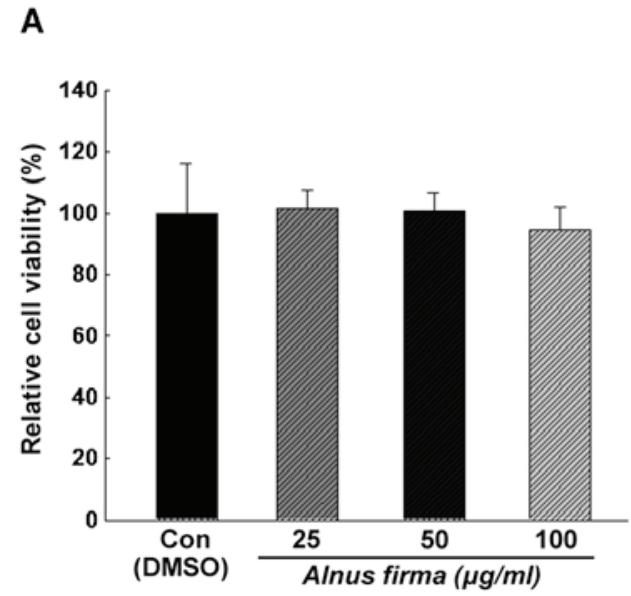

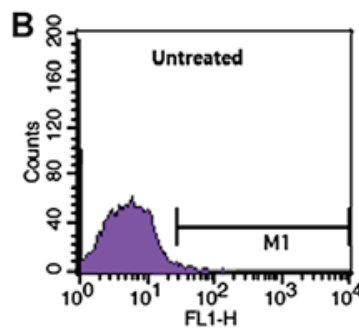
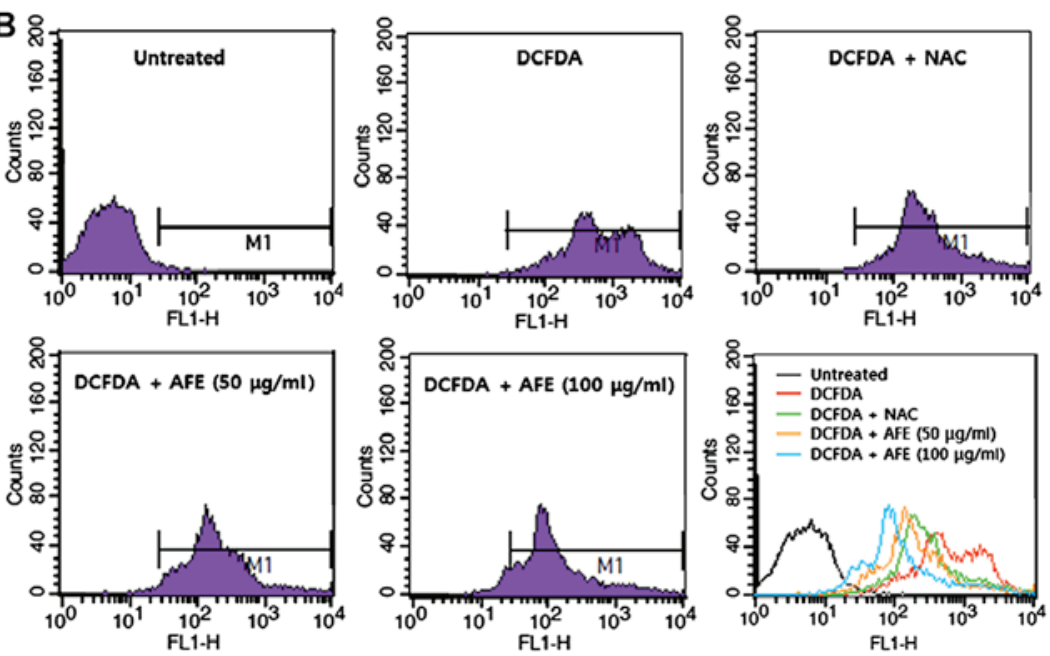

Figure 3. (A) Effect of AFE on the viability of 3T3-L1 preadipocytes determined by an XTT assay. (B) During adipogenesis of 3T3-L1, the reactive oxygen species levels were measured by fluorescence-assisted cell sorting. All values are expressed as the mean \pm standard deviation. AFE, $70 \%$ ethanolic extract of Alnus firma; CON, control group; DMSO, dimethyl sulfoxide; DCFDA, 2',7'-dichlorodihydrofluorescein diacetate; NAC, N-acetyl-L-cysteine.

treating 3T3-L1 preadipocytes, the XTT assay was performed. The cytotoxicity of AFE at various concentrations was analyzed by calculating the degree of change in cell growth as a percentage of the mock control group. As presented in Fig. 3A, AFE did not have any cytotoxic effects at 25, 50 and $100 \mu \mathrm{g} / \mathrm{ml}$ concentration and the absorbance values were $101 \pm 6.3,100 \pm 6.1$ and $94 \pm 7.6 \%$ of the control values, respectively, after $24 \mathrm{~h}$ of incubation. Also, no changes in cell morphology were observed under the microscope (data not shown). Thus, the concentrations of 25,50 and $100 \mu \mathrm{g} / \mathrm{ml}$ were used in the experiments described below.

Determination of ROS by flow cytometry. The inhibition of ROS production during the differentiation of 3T3-L1 cells by AFE was analyzed using $\mathrm{H}_{2}$ DCFDA. Treatment with AFE (50 or $100 \mu \mathrm{g} / \mathrm{ml}$ ) or NAC during the adipogenic stage (days 0-6 post-induction) resulted in a inhibition of ROS generation compared with that in a control group, which was only treated with MDI for induction. As presented in Fig. 3B, the production of ROS was increased during adipocyte differentiation, which was inhibited in the presence of NAC or AFE. It was also revealed that the production of ROS was decreased by AFE in a dose-dependent manner, although statistical analysis was not conducted on this data.

Effects of AFE on lipid accumulation and ROS production during adipocyte differentiation. The present study examined the capacity of AFE to inhibit adipogenic differentiation of preadipocytes. Treatments with AFE (25, 50 and $100 \mu \mathrm{g} / \mathrm{ml}$ ) and NAC during adipogenic differentiation (days $0-8$ post-induction) resulted in a significant inhibition of lipid accumulation compared with that in the control group. The 3T3-L1 cells treated with NAC also displayed significantly reduced lipid accumulation $(23 \pm 3.1 \%$ compared with that in the control) (Fig. 4A). While AFE at $25 \mu \mathrm{g} / \mathrm{ml}$ did not affect the lipid accumulation (101 $\pm 6.6 \%$ of control), 50 and $100 \mu \mathrm{g} / \mathrm{ml}$ of AFE significantly reduced lipid accumulation to $92 \pm 3.4$ and $71 \pm 6.8 \%$, respectively, compared with the mock control. Next, the effect of AFE on ROS production in 3T3-L1 during adipogenic differentiation was examined using an NBT assay. Treatment with AFE $(25,50$ or $100 \mu \mathrm{g} / \mathrm{ml})$ or NAC during adipogenic differentiation (days $0-8$ post-induction) resulted in a significant inhibition of ROS accumulation. NAC-treated cells displayed significantly reduced ROS levels (20 $\pm 2.5 \%$ compared with the control) (Fig. 4B). Cells treated with AFE at all concentrations $(25,50$ and $100 \mu \mathrm{g} / \mathrm{ml})$ exhibited drastically reduced ROS production $(87 \pm 6.2,57 \pm 3.8$ and $40 \pm 1.6 \%$, respectively, compared to mock control). These results indicated that lipids accumulate in parallel with ROS production during adipogenesis, which is dose-dependently inhibited by AFE.

Effect of AFE on the expression of factors associated with lipid accumulation during differentiation. In order to determine whether AFE inhibitis adipogenic mechanisms, the mRNA (Fig. 5A and B) and protein (Fig. 5C and D) expression levels of the adipogenic transcription factors PPAR $-\gamma$, C/EBP- $\alpha$ and aP2 in 3T3-L1 cells treated with 50 and $100 \mu \mathrm{g} / \mathrm{ml}$ of AFE or NAC during differentiation were assessed by RT-PCR and western blot analysis, respectively. The results in Fig. 5 demonstrate that in 3T3-L1 cells treated with $100 \mu \mathrm{g} / \mathrm{ml}$ AFE during differentiation, PPAR- $\gamma, \mathrm{C} / \mathrm{EBP}-\alpha$ and aP2 levels were decreased to 12,21 and $6 \%$ of those in the control group, respectively. In addition, the protein expression levels of PPAR- $\gamma, \mathrm{C} / \mathrm{EBP}-\alpha$ and aP2 in 3T3-L1 cells treated with $100 \mu \mathrm{g} / \mathrm{ml}$ AFE during differentiation were significantly decreased to 62,8 and $16 \%$ of those in the control group, respectively. These results were similar to those in the positive control group treated with NAC.

\section{Discussion}

The members of the botanical genus Alder have been reviewed for their biological activities, including certain common species with importance in traditional medicine. Plant species of the genus Alder have been used for treating hemorrhage, burn injuries, fever, diarrhea and alcoholism in traditional Korean medicine. The stems of these plants are available on 

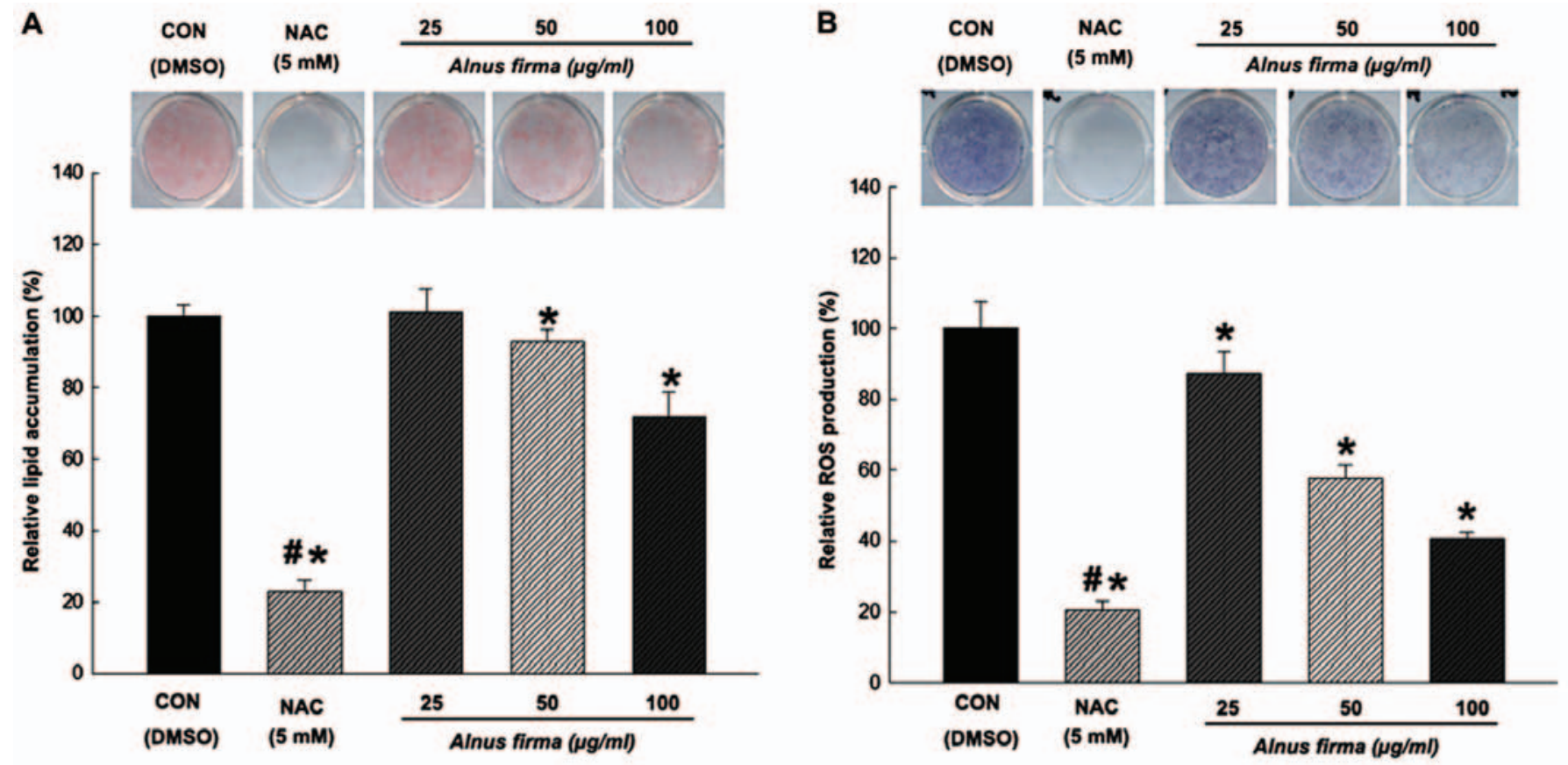

Figure 4. Effect of the AFE on (A) lipid accumulation and (B) ROS production in 3T3-L1 cells during adipogenesis. Accumulated lipids were stained with Oil Red O reagent and the absorbance at $490 \mathrm{~nm}$ was measured. ROS production was assessed based on the formation of dark-blue formazan and determined by the nitroblue tetrazolium assay at a wavelength of $570 \mathrm{~nm}$. All values are expressed as the mean \pm standard deviation. ${ }^{*} \mathrm{P}<0.05 \mathrm{vs} . \mathrm{CON} ;{ }^{*} \mathrm{P}<0.05 \mathrm{vs} .100 \mu \mathrm{g} / \mathrm{ml}$ AFE, according to one-way analysis of variance. Groups: CON, control cells that were differentiated with MDI; NAC, positive control cells that were differentiated with MDI in the presence of NAC. AFE, 70\% ethanolic extract of Alnus firma; DMSO, dimethyl sulfoxide; NAC, N-acetyl-L-cysteine; ROS, reactive oxygen species; MDI, hormone cocktail of isobutyl methylxanthine, dexamethasone and insulin.
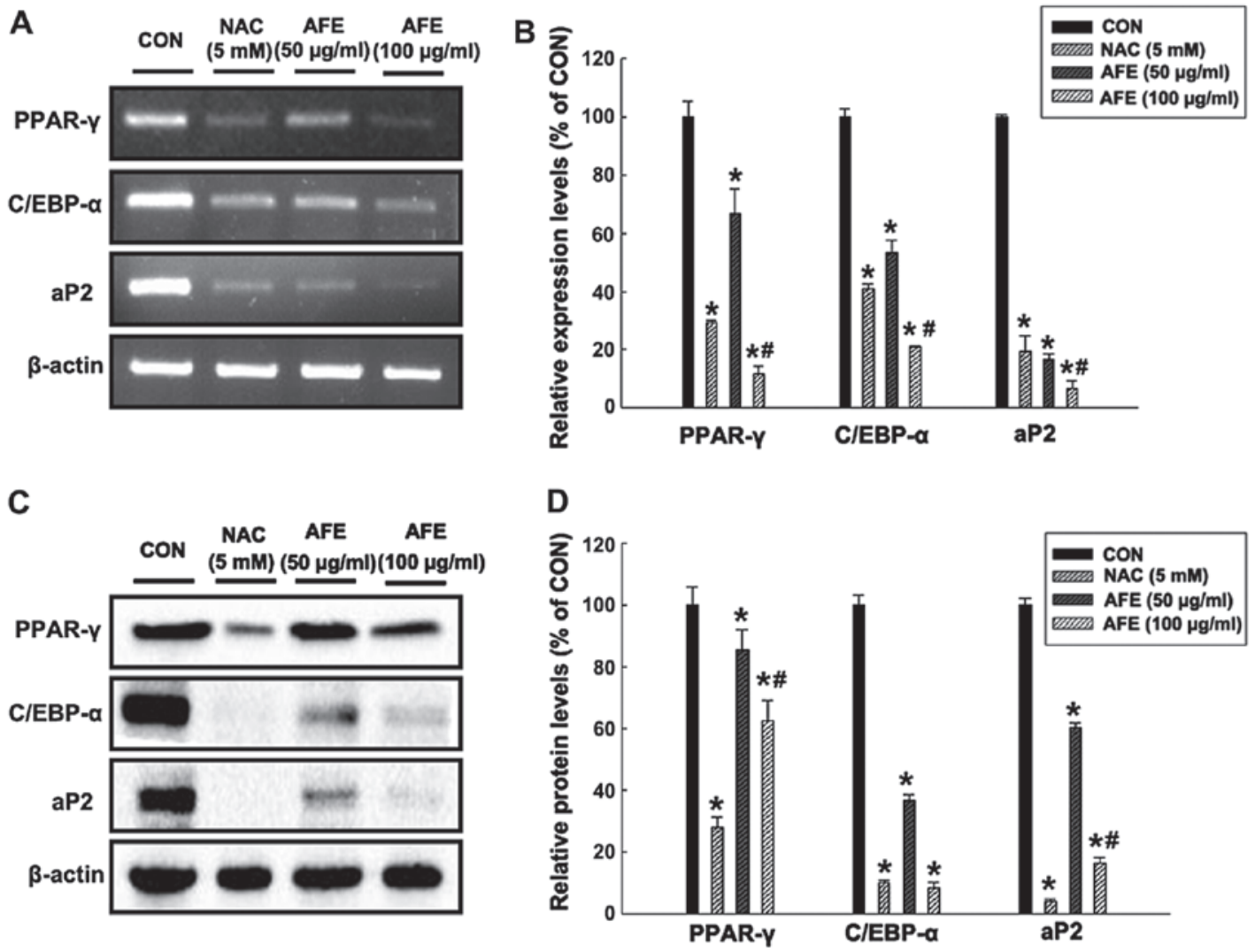

Figure 5. AFE inhibits the mRNA and protein expression of adipogenic transcription factors in 3T3-L1 adipocytes. Cells were pretreated without or with different concentrations of AFE (50 and $100 \mu \mathrm{g} / \mathrm{ml})$ and $5 \mathrm{mM}$ NAC. The (A and B) mRNA and (C and D) protein expression of PPAR- $\gamma, \mathrm{C} / \mathrm{EBP}-\alpha$ and aP2 was measured by polymerase chain reaction and western blot analysis, respectively. Expression levels were densitometrically quantified with normalization to the control. All values are expressed as the mean \pm standard deviation. ${ }^{*} \mathrm{P}<0.05$ vs. CON; ${ }^{\#} \mathrm{P}<0.05$ vs. NAC $5 \mathrm{mM}$, according to one-way analysis of variance. AFE, 70\% ethanolic extract of Alnus firma; NAC, N-acetyl-L-cysteine; CON, control; PPAR- $\gamma$, peroxisome proliferator-activated receptor- $\gamma ; \mathrm{C} / \mathrm{EBP}-\alpha$, CCAAT/enhance-binding protein $\alpha$; aP2, adipocyte protein 2. 
oriental herb market in the form of a health tea for treating alcoholism in Korea. Evidence from pharmacological studies has suggested that these species have anti-inflammatory, antitumor, anti-obesity and anti-oxidative effects $(34,35)$. The present study demonstrated the antioxidant effects, and the inhibition of lipid accumulation and ROS production by AFE during the adipogenesis of 3T3-L1 cells.

Plants contain numerous phytochemicals, including proanthocyanidins, phenolics and flavonoids, which provide a number of benefits to the human body (36). Of these phytochemicals, the genus Alder contains flavonoids and phenols (34). Numerous studies suggested that these compounds are important antioxidant substances that act as reducing agents, singlet oxygen quenchers or electron donors with chelating properties $(37,38)$. Therefore, the total anthocyanin, phenolic and flavonoid content of AFE were investigated and the results indicated their presence at high levels. Comparison of the levels of these components among other species of the genus Alder reported in the literature indicated that their levels were not low at all. A. firma was determined to be of medicinal value due to the high levels of phenolic compounds.

The DPPH radical has the capacity to compromise the stability of molecules. It accepts an electron or hydrogen radical from ascorbic acid, tocopherol, polyhydroxy aromatic compounds and aromatic amines. In the DPPH assay, this reaction triggers a color change from purple to yellow measured at $\mathrm{OD}_{517}$, and which may be interfered with by radical-quenching substrates (39). This principle has been widely used to explore the antioxidant activity of a variety of natural materials, as this method is quick, reliable and reproducible (40). The ABTS radical scavenging activity assay was also applied. The ABTS radical generated by reaction with potassium persulfate is quenched by the antioxidant substrate at different concentrations in the sample, which leads to changes in color that are detected at $734 \mathrm{~nm}$ (41). Another antioxidant activity assay, the reducing power is usually associated with the presence of reductones, which exert their antioxidant effects by breaking the free radical chain via donating a hydrogen atom (42). Ferric-ferricyanide $\left(\mathrm{Fe}^{3+}\right)$ stabilizes the free radical by sharing a hydrogen atom, and is thereby reduced to a ferrous ion $\left(\mathrm{Fe}^{2+}\right)$ and the reducing power is quantified by measuring the $\mathrm{OD}_{700}$ (20). The nitrite scavenging ability is also associated with the antioxidant capacity. Nitrite radicals react with Griess reagent to form a purple Azo dye. In this method, the nitrite scavenging activity is measured by colorimetric determination with the color change being proportional to the concentration of nitrite (21). Finally, the ORAC assay is a method of measuring the antioxidant activity of a sample via the reduction of fluorescein by peroxyl radicals. When the peroxyl radical is generated by 2,2'-azobis(2-methylpropionamidine) dihychloride, the antioxidants in the sample maintain the fluorescence by removing the peroxyl radicals, which would oxidize the fluorescein, until the antioxidants in the sample are depleted. The antioxidant capacity of the sample over time is represented by a decay curve and quantified by comparison with a standard, which is water-soluble vitamin E (Trolox) (22). In general, these analytical methods assessing various radical-quenching and antioxidant effects should be employed for the evaluation of the antioxidant activity of a compound, as ROS are formed by a number of different mechanisms and may be detected by various techniques. AFE were evaluated using these methods, revealing that it had a high radical-quenching and antioxidant capacity, and all antioxidant values increased in a dose-dependent manner. Due to these effects, A. firma is considered to have a wide applicability as a functional food supplement.

The effects of the AFE on lipid accumulation and ROS production during the differentiation of 3T3-L1 cells were determined by Oil Red $\mathrm{O}$ staining and the NBT assay. Two-days post-confluent 3T3-L1 preadipocytes (day 0) were treated with AFE $(25,50$ or $100 \mu \mathrm{g} / \mathrm{ml})$ every other day for 8 days. When the preadipocytes were differentiated into adipocytes via the application of the MDI cocktail, morphological changes were observed due to the accumulation of lipid droplets in the cytoplasm. During the differentiation of 3T3-L1 cells from preadipocytes to adipocytes, the neutral lipids produced during this process were detected by Oil Red $\mathrm{O}$ staining, with red droplets displaying in the cells. A greater amount of reddish 3T3-L1 cells indicated more lipid accumulation and represented the extent of adipogenesis. The absorbance of cells treated with AFE or NAC during adipogenesis was compared with that of the control that was only induced with MDI. NAC is a well-known inhibitor used as a positive control during adipogenensis and causes a significant reduction in lipid accumulation in 3T3-L1 cells (43). The results of the present study indicated significantly reduced lipid accumulation in the cells treated with AFE during differentiation. This result means that A. firma was effective in reducing lipid accumulation in preadipocytes during adipogenesis. Numerous studies have emphasized the link between oxidative stress and obesity (24). It is expected that the reduction of ROS production and the reduction in lipid accumulation by AFE has a positive impact to interfere with obesity-associated processes. In this context, the NBT assay and flow cytometry were used to measure ROS production during adipocyte differentiation. The NBT assay is a well-established technique that is used to quantify the cellular oxidative metabolism (44). In this assay, the NBT reagent reacts with ROS accumulating in the 3T3-L1 cells to produce dark-blue formazan crystals, which are then densitometrically quantified after being dissolved to determine the amount of ROS production. The $\mathrm{H}_{2}$ DCFDA assay is one of the most widely used methods for directly measuring the reductive and oxidative states of cells. In particular, it is sensitive to changes in the redox state of cells and may be used to monitor changes in the quantity of ROS over time (45). The results of the present study demonstrated significantly reduced ROS accumulation in the presence of different concentrations of AFE during adipogenesis. This reduction of ROS accumulation by AFE was in parallel with inhibition of lipid accumulation, further indicating a link between the two processes.

The anti-obesity effects of extracts from natural resources may be screened through in vitro inhibition of adipocyte differentiation and of lipid accumulation in 3T3-L1 cells (46). The differentiation of confluent preadipocytes into adipocytes requires a variety of effectors that activate a cascade of transcription factors, including $\mathrm{C} / \mathrm{EBP}-\alpha$ and PPAR $-\gamma$. PPAR $-\gamma$ induces most adipocyte-specific genes, including aP2 (47), which is a marker gene for adipogenesis and has a critical role in the regulation of gene expression during early development $(48,49)$. In the present study, AFE downregulated the 
mRNA and protein expression levels of PPAR- $\gamma, \mathrm{C} / \mathrm{EBP}-\alpha$ and aP2. It was therefore suggested that A. firma has beneficial anti-adipogenic effects.

In conclusion, the present study evaluated the antioxidant capacity of AFE, as well as its effects on lipid accumulation and ROS production during adipogenesis of 3T3-L1 cells. The total phenolic and flavonoid content of AFE were assessed. Various measurement methods were applied for assessing the antioxidant activity, including the DPPH and the ABTS radical scavenging, reducing power and ORAC assays, revealing that AFE exhibited significant antioxidant activity. Furthermore, AFE decreased lipid accumulation and ROS production in 3T3-L1 cells. In addition, AFE downregulated the mRNA and protein expression levels of PPAR- $\gamma, \mathrm{C} / \mathrm{EBP}-\alpha$ and aP2. Based on these results, A. firma was revealed to possess antioxidant and anti-adipocyte activities and to be potentially beneficial in preventing obesity.

\section{Acknowledgements}

This study was supported by a grant from the National Institute of Biological Resources (NIBR), funded by the Ministry of Environment of the Republic of Korea (grant no. NIBR201628101).

\section{References}

1. Dröge W and Dröge W: Free radicals in the physiological control of cell function. Physiol Rev 82: 47-95, 2002.

2. Halliwell B, Aeschbach R, Löliger J and Aruoma OI: The characterization of antioxidants. Food Chem Toxicol 33: 601-617, 1995.

3. Valko M, Leibfritz D, Moncol J, Cronin MT, Mazur M and Telser J: Free radicals and antioxidants in normal physiological functions and human disease. Int J Biochem Cell Biol 39: 44-84, 2007.

4. Yamashina K, Miller BE and HeppnerGH: Macrophage-mediated induction of drug-resistant variants in a mouse mammary tumor cell line. Cancer Res 46: 2396-2401, 1986.

5. Fridovich I: Superoxide dismutases. An adaptation to a paramagnetic gas. J Biol Chem 264: 7761-7764, 1989.

6. Spiegelman BM and Flier JS: Obesity and the regulation of energy balance. Cell 104: 531-543, 2001.

7. Marcelin G and Chua S Jr: Contributions of adipocyte lipid metabolism to body fat content and implications for the treatment of obesity. Curr Opin Pharmacol 10: 588-593, 2010.

8. Holst D and Grimaldi PA: New factors in the regulation of adipose differentiation and metabolism. Curr Opin Lipidol 13: 241-245, 2002.

9. de Ferranti S and Mozaffarian D: The perfect storm: Obesity, adipocyte dysfunction, and metabolic consequences. Clin Chem 54: 945-955, 2008.

10. Lee OH, Kwon YI, Hong HD, Park CS, Lee BY and Kim YC: Production of reactive oxygen species and changes in antioxidant enzyme activites during differentiation of 3T3-L1 adipocyte. J Korean Soc Appl Biol Chem 52: 70-75, 2009.

11. Sureda A, Tauler P, Aguiló A, Cases N, Fuentespina E, Córdova A Tur JA and Pons A: Relation between oxidative stress markers and antioxidant endogenous defences during exhaustive exercise. Free Radic Res 39: 1317-1324, 2005.

12. Kim HK, Kwon YJ, Kim YE and Nahmgang B: Changes of total polyphenol content and antioxidant activity of aster scaber thunb extracts with different microwave assisted extraction conditions. Korean J Food Preserv 11: 88-95, 2004.

13. Larson RA: The antioxidants of higher plants. Phytochemistry 27: 969-978, 1988

14. Schöner S and Heinrich Krause G: Protective systems against active oxygen species in spinach: Response to cold acclimation in excess light. Planta 180: 383-389, 1990.

15. Gutfinger T: Polyphenols in olive oils. J Am Oil Chem Soc 58: 966-968, 1981.
16. Moreno MI, Isla MI, Sampietro AR and Vattuone MA: Comparison of the free radical-scavenging activity of propolis from several regions of Argentina. J Ethnopharmacol 71: 109-114, 2000

17. Mitsunaga T, Doi T, Kondo Y and Abe I: Color development of proanthocyanidins in vanillin-hydrochloric acid reaction. J Wood Sci 44: 125-130, 1998.

18. Chu YH, Chang CL and Hsu HF: Flavonoid content of several vegetables and their antioxidant activity. J Sci Food Agric 80: 561-566, 2000.

19. Re R, Pellegrini N, Proteggente A, Pannala A, Yang M and Rice-Evans C: Antioxidant activity applying an improved ABTS radical cation decolorization assay. Free Radic Biol Med 26: 1231-1237, 1999.

20. Oyaizu M: Antioxidative activities of browning products of glucosamine fractionated by organic solvent and thin-layer chromatography. J Jpn Soc Food Sci 35: 771-775, 1988.

21. Kato H, Lee IE, Chuyen NV, Kim SB and Hayase F: Inhibition of nitrosamine formation by nondialyzable melanoidins. Agric Biol Chem 51: 1333-1388, 1987.

22. Ou B, Hampsch-Woodill M and Prior RL: Development and validation of an improved oxygen radical absorbance capacity assay using fluorescein as the fluorescent probe. J Agric Food Chem 49: 4619-4626, 2001

23. Lee OH, Kwon YI, Apostolidis E, Shetty K and Kim YC: Rhodiola-induced inhibition of adipogenesis involves antioxidant enzyme response associated with pentose phosphate pathway. Phytother Res 25: 106-115, 2011.

24. Furukawa S, Fujita T, Shimabukuro M, Iwaki M, Yamada Y, Nakajima Y, Nakayama O, Makishima M, Matsuda M and Shimomura I: Increased oxidative stress in obesity and its impact on metabolic syndrome. J Clin Invest 114: 1752-1761, 2004.

25. Blumberg JM, Tzameli I, Astapova I, Lam FS, Flier JS and Hollenberg AN: Complex role of the vitamin D receptor and its ligand in adipogenesis in 3T3-L1 cells. J Biol Chem 281: 11205-11213, 2006.

26. Kaur C and Kapoor HC: Antioxidant activity and total phenolic content of some Asian vegetables. Int J Food Sci Technol 37: 153-161, 2002.

27. Machowetz A, Poulsen HE, Gruendel S, Weimann A, Fitó M, Marrugat J, de la Torre R, Salonen JT, Nyyssönen K, Mursu J, et al: Effect of olive oils on biomarkers of oxidative DNA stress in Northern and Southern Europeans. FASEB J 21: 45-52, 2007.

28. Heim KE, Tagliaferro AR and Bobilya DJ: Flavonoid antioxidants: Chemistry, metabolism and structure-activity relationships. J Nutr Biochem 13: 572-584, 2002.

29. Fine AM: Oligomeric proanthocyanidin complexes: History, structure, and phytopharmaceutical applications. Altern Med Rev 5: 144-151, 2000.

30. Stević T, Savikin K, Zdunić G, Stanojković T, Juranić Z, Janković T and Menković N: Antioxidant, cytotoxic, and antimicrobial activity of Alnus incana (L.) ssp. incana Moench and A. viridis (Chaix) DC ssp. viridis extracts. J Med Food 13: 700-704, 2010.

31. Acero $\mathrm{N}$ and Muñoz-Mingarro D: Effect on tumor necrosis factor- $\alpha$ production and antioxidant ability of black alder, as factors related to its anti-inflammatory properties. J Med Food 15: 542-548, 2012.

32. Li H, Choi YM, Lee JS, Park JS, Yeon KS and Han CS: Drying and antioxidant characteristics of the shiitake (Lentinus edodes) mushroom in a conveyer type far-infrared dryer. J Korean Soc Food Sci Nutr 36: 250-254, 2007.

33. Kim MB, Hyun SH, Park JS, Kang M, Ko YH and Lim SB: Integral antioxidative capacity of extracts by pressurized organic solvent from natural plants in Jeju. J Korean Soc Food Sci Nutr 37: 1491-1496, 2008.

34. Sati SC, Sati N and Sati OP: Bioactive constituents and medicinal importance of genus Alnus. Pharmacogn Rev 5: 174-183, 2011.

35. Lee M, Song JY, Chin YW and Sung SH: Anti-adipogenic diarylheptanoids from Alnus hirsuta f. sibirica on 3T3-L1 cells. Bioorg Med Chem Lett 23: 2069-2073, 2013.

36. Hanasaki Y, Ogawa S and Fukui S: The correlation between active oxygens scavenging and antioxidative effects of flavonoids. Free Radic Biol Med 16: 845-850, 1994.

37. Rice-Evans CA, Miller NJ and Paganga G: Structure-antioxidant activity relationships of flavonoids and phenolic acids. Free Radic Biol Med 20: 933-956, 1996.

38. Cao G, Sofic E and Prior RL: Antioxidant and prooxidant behavior of flavonoids: Structure-activity relationships. Free Radic Biol Med 22: 749-760, 1997. 
39. MacDonald-Wicks LK, Wood LG and Garg ML: Methodology for the determination of biological antioxidant capacity in vitro: A review. J Sci Food Agric 86: 2046-2056, 2006.

40. Que F, Mao L, Zhu C and Xie G: Antioxidant properties of Chinese yellow wine, its concentrate and volatiles. LWT Food Sic Technol 39: 111-117, 2006.

41. Tachakittirungrod S, Okonogi S and Chowwanapoonpohn S: Study on antioxidant activity of certain plants in Thailand: Mechanism of antioxidant action of guava leaf extract. Food Chem 103: 381-388, 2007.

42. Duh PD: Antioxidant activity of burdock (Arctium lappa Linné): Its scavenging effect on free-radical and active oxygen. J Am Oil Chem Soc 75: 455-461, 1998

43. Calzadilla P, Sapochnik D, Cosentino S, Diz V, Dicelio L, Calvo JC and Guerra LN: N-acetylcysteine reduces markers of differentiation in 3T3-L1 adipocytes. Int J Mol Sci 12: 6936-6951, 2011.

44. Baehner RL, Boxer LA and Davis J: The biochemical basis of nitroblue tetrazolium reduction in normal human and chronic granulomatous disease polymorphonuclear leukocytes. Blood 48: 309-313, 1976
45. Eruslanov E and Kusmartsev S: Identification of ROS using oxidized DCFDA and flow-cytometry. Methods Mol Biol 594: $57-72,2010$

46. Morrison RF and Farmer SR: Insights into the transcriptional control of adipocyte differentiation. J Cell Biochem 33 (Suppl 32): 59-67, 1999.

47. Tontonoz P, Hu E, Graves RA, Budavari AI and Spiegelman BM: mPPAR gamma 2: Tissue-specific regulator of an adipocyte enhancer. Genes Dev 8: 1224-1234, 1994.

48. Hilger-Eversheim K, Moser M, Schorle H and Buettner R: Regulatory roles of AP-2 transcription factors in vertebrate development, apoptosis and cell-cycle control. Gene 260: 1-12, 2000.

49. Makowski L and Hotamisligil GS: Fatty acid binding proteins the evolutionary crossroads of inflammatory and metabolic responses. J Nutr 134: 2464S-2468S, 2004.

This work is licensed under a Creative Commons Attribution-NonCommercial-NoDerivatives 4.0 International (CC BY-NC-ND 4.0) License. 